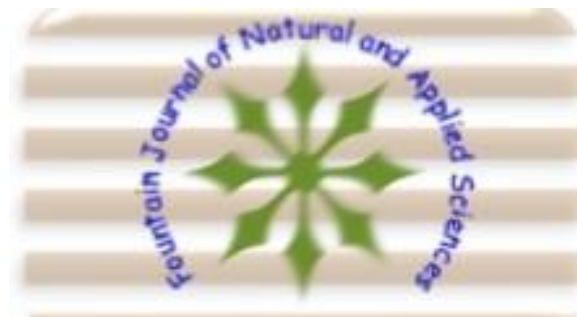

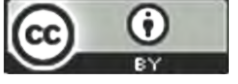

This work is licensed under Creative Commons Attribution 4.0 International License.

DOI: 10.53704/fujnas.v6i2.151

A publication of College of Natural and Applied Sciences, Fountain University, Osogbo, Nigeria.

Journal homepage: www. fountainjournals.com

ISSN:2354-337X(Online),2350-1863(Print)

\title{
Effect of Aqueous Extract of Senna occidentalis Leaves on Haematological and Liver Biochemical Parameters in Wistar Rats
}

\author{
*Owolarafe, T.A., Fadilu, M., Salawu, K., Ononamadu, C. J., Lawal, A. T., Ihegboro, G. O. and \\ Barau, M. M.
}

Department of Biochemistry and Forensic Science, Nigeria Police Academy, P.M.B 3474 Wudil, Kano State, Nigeria.

\begin{abstract}
This study evaluated the effect of aqueous extract of Senna occindentalis leaves on some biochemical parameters in Wistar rats. Twenty albino rats equally divided into four experimental groups were used. One group served as control and received the carrier solvent treatment. Three test groups were treated with $S$. occidentalis extract at 500, 1000 and $1500 \mathrm{mg} / \mathrm{kg}$ body weight respectively. The experiment lasted for 14 days after which the rats were sacrificed and blood collected for biochemical and haematological evaluation. Liver-body weight ratio was computed and liver histoarchitecture was investigated. The results showed that all haematological parameters were significantly ( $P<0.05)$ affected except the mean corpuscular haemoglobin concentration and mean corpuscular volume. There were also significant $(P<0.05)$ alterations in the activities of gamma-glutamyl transferase, alanine aminotransferase, and aspartate aminotransferase, as well as the levels of total protein, albumin and globulin in the serum. No significant ( $P>0.05)$ alterations were observed in the computed liver-body weight ratio but marked alterations in histoarchitecture of the liver cells were present. These alterations in the haematological parameters, liver function enzymes and histological evaluation suggest a selective toxicity of the extract on the animals.
\end{abstract}

Keywords: Senna occindetalis, aqueous extract, gamma-glutamyl transferase, haematology, histology.

\section{Introduction}

Plants are endowed with various phytochemical molecules such as vitamins, terpenoids, phenolic acids, lignins and other secondary metabolites (Cai et al., 2003; Zheng and Wang, 2003) because they are plants derived molecules, they are often perceived as "natural" and therefore "safe" (Debelo et al., 2016). The value of these medicinal plants in drug discovery is known with their traditional folk remedies which have always guided scientists to search for new medications in order to maintain and promote healthy life for humans and animals (Achterberg, 2013).
Indiscriminate use of these plant extracts, either as concoction or infusion, at the primary health care level all over the world (WHO, 2008) and lack of standardized dose regimen have placed the human subject at great risk of toxic effect of these plant extracts. subtropical regions of the world, including Nigeria, It is commonly known as coffee senna (Haselwood and Motter, 1966), stinking weed (Henty

\footnotetext{
*Corresponding author: +2347067959611

Email address: abufatimawamaryam@gmail.com
} 
et al., 1975) and in Nigeria, it is called Rai dorai in Hausa language (northern Nigeria) (Blench, 2007). The folklore uses have been reported for antiseptic, analgesic and anti-inflammatory properties (Gained et al., 1966). A number of research reports have also published on Senna occidentalis such as its hepatoprotective effect (Nwaehujor et al., 2011) antimicrobial and antioxidant activities (Odeja, et al., 2016).

Inspite of the myriad of uses to which this plant has been put, reports on its safety have remained scanty in the open literature. This study therefore aimed at providing information on the safety of aqueous leaf extract of Senna occidentalis by evaluating its effects on haematological parameters, indices of liver damage, and liver histoarchitecture of Wistar rats.

\section{Materials and Methods}

\section{Plant Material and Authentication}

Fresh leaves of $S$. occidentalis were collected from a single population within the premises of Nigeria Police Academy, Wudil Local Government Area, Kano State, Nigeria and was identified and authenticated at the Department of Plant Biology Herbarium, Bayero University, Kano with voucher number BUKHAN73.

\section{Assay Kits And Enzyme Substrates}

The assay kit for gamma-glutamyl transferase (GGT) was a product of Agape Diagnostics Switzerland. Albumin and total protein kits were products of Randox Laboratories Ltd, U.K., while assay kits for alanine and aspartate aminotransferases (ALT and AST, respectively) were products of TECO diagnostics U.S.A. All other reagents used were of analytical grade.

\section{Preparation Of Extract}

The fresh leaves were dried in the shade for two (2) weeks, pulverized into powder and stored in a plastic container. The pulverized leaves of Senna occidentalis were weighed and $1000 \mathrm{~g}$ of the powdered material were macerated and extracted in $2000 \mathrm{ml}$ of distilled water for 72 hours. The extracted sample was sieved and filtered using sieve cloth and Whatman filter paper (Number 1). The filtrate was concentrated and used for the study.

\section{Animal Grouping and Extract Administration}

A total of twenty healthy adult Wistar rats weighing 160-220 $g$ were acclimatised to the laboratory conditions for 7 days prior to the experiment. The animals were fed rat pellet diet and layers mesh, exposed to approximately $12 \mathrm{~h}$ light: 12 $h$ dark cycle and water was provided ad libitum. Animals were treated humanely; veterinary care and supervision were provided throughout the period of study. Group 1 was administered distilled water orally by orogastric cannula. Groups 2, 3 and 4 were administered 500,1000 and $1500 \mathrm{mg} / \mathrm{kg}$ body weight, respectively, of the extract of $S$. ocidentallis leaves.

\section{Haematological Analysis}

Blood sample was collected from all the test rats and control rats according the methods described by Yakubu et al. (2007). The jugular viens were exposed and cut with a surgical blade under mild chloroform anaesthesia. Blood samples were collected into two (2) different sample heparinised test tubes for each rat. The anticoagulated blood samples were used for haematological analysis, i.e. haemoglobin concentration $(\mathrm{Hb})$, red blood cells $(R B C)$, total white blood cell (WBC) count, and packed cell volume (PCV) using automated haematological analyzer (Mindray KX-21, Japan ). Sterile test tubes were used to collect blood samples for serum biochemical analysis, preceded by centrifuging at $300 \mathrm{rpm}$ for $10 \mathrm{~min}$ using Bench-top Laboratory Centrifuge and subsequently separated using Pasteur pipette.

\section{Determination of Biochemical Parameters}

The activity of serum GGT was assayed according to the method of Szasz and Bergmeyer (1974). ALT and AST were determined in the serum according to the method described by Henry (1984). Total protein concentration was determined as described by Tietz (1994) and albumin concentration was determined by the method of Grant et al. (1987). Globulin concentration was determined by subtraction of albumin from total protein concentration.

The liver-body weight ratio was determined according to the protocol described by Krause 
(2001), while histopathological evaluation protocol was according to Auwioro (2010). The liver was quickly removed from the animals and cleansed of blood. It was weighed and liver-body weight ratio was determined by dividing the weight of the liver by the body weight of the animal and expressed as percentage. The tissues were fixed with $10 \%$ neutral buffered formalin, were dehydrated through ascending grades of ethanol $(70 \%, 90 \%$ and $95 \% \mathrm{v} / \mathrm{v})$. They were cleaned in toluene, infiltrated and embedded with molten paraffin wax (melting point $56^{\circ} \mathrm{C}$ ), the sections were cut at $5 \mu \mathrm{m}$ on a rotatory microtone. The sections were stained with haematoxylin and eosin staining technique and examined with leica DM750 microscope and photographed with leica ICCSOHD camera.

\section{Statistical Analysis}

The data obtained from the studies were represented as Mean \pm SEM. The data were analyzed by one way analysis of variance (ANOVA), ' $P$ ' value less than 0.05 was considered as statistically significant. Graphpad Instat version 3.05 and Microsoft Excel 2007 were used for statistical analysis and production of tables.

\section{Results}

The haematological parameters observed after extract administration are as presented in Table 1. There were no significant $(P>0.05)$ differences between the treated groups and when compared with the control for $\mathrm{MCH}, M C H C$ and $M C V$ except $M C H$ at $1500 \mathrm{mg} / \mathrm{kg}$ treated group with a significant $(P<0.05)$ decrease. There were significant $(P<0.05)$ reductions in haemoglobin concentration, RBC and $P C V$ and significant $(P<0.05)$ increase in MID at 1000 and 1500 $\mathrm{mg} / \mathrm{kg}$ body weight. There were significant increase $(P<0.05)$ in all experimental groups for WBC compared with the control while a significant $(P<0.05)$ increase was also observed in lymphocyte counts at $1000 \mathrm{mg} / \mathrm{kg}$ body weight. Significant reductions $(P<0.05)$ were observed in neutrophil and platelet counts at $1000 \mathrm{mg} / \mathrm{kg}$ body weight while a significant $(P<0.05)$ increase in platelet count was observed at $1500 \mathrm{mg} / \mathrm{kg}$ body weight (Table 1 ).

Table 1: Effect of aqueous extract of Senna occidentalis leaves on some haematological parameters of Wistar rats

\begin{tabular}{|c|c|c|c|c|}
\hline \multirow[t]{2}{*}{ Parameters } & \multicolumn{4}{|c|}{ Senna occidentalis aqueous extract (mg/kg body weight) } \\
\hline & Control & 500 & 1000 & 1500 \\
\hline Haemoglobin $(g / L)$ & $14.00 \pm 0.73^{a}$ & $14.13+0.35^{a}$ & $10.27 \pm 0.24^{b}$ & $10.37 \pm 0.29^{b}$ \\
\hline Red blood cell $\left(\times 10^{12} / \mathrm{L}\right)$ & $8.21+0.41^{a}$ & $8.37 \pm 0.25^{a}$ & $6.56 \pm 0.47^{b}$ & $6.52+0.18^{b}$ \\
\hline Packed cell volume (\%) & $41.00 \pm 2.09^{a}$ & $41.03 \pm 1.35^{a}$ & $31.20 \pm 1.46^{b}$ & $30.63 \pm 0.81^{b}$ \\
\hline $\begin{array}{l}\text { Mean corpuscular haemoglobin } \\
\text { (pg) }\end{array}$ & $16.97 \pm 0.05^{a}$ & $16.60 \pm 0.04^{a}$ & $16.97 \pm 0.28^{a}$ & $15.87 \pm 0.08^{b}$ \\
\hline $\begin{array}{l}\text { Mean corpuscular haemoglobin } \\
\text { concentration }(\%)\end{array}$ & $34.07 \pm 0.12^{a}$ & $33.60 \pm 0.11^{a}$ & $33.60 \pm 0.11^{a}$ & $33.67 \pm 0.15^{a}$ \\
\hline Mean corpuscular volume $(\mathrm{fl})$ & $50.00 \pm 0.28^{a}$ & $48.77 \pm 0.41^{a}$ & $48.00 \pm 1.28^{a}$ & $47.20 \pm 0.41^{a}$ \\
\hline White blood cell $\left(\times 10^{9} / L\right)$ & $7.67 \pm 0.51^{a}$ & $11.54 \pm 0.29^{b}$ & $36.76 \pm 3.19^{c}$ & $11.40 \pm 0.58^{b}$ \\
\hline Lymphocytes (x109/L) & $54.67 \pm 1.38^{a}$ & $55.00 \pm 1.67^{a}$ & $67.47 \pm 5.52^{b}$ & $56.33 \pm 2.43^{a}$ \\
\hline Neutrophils $\left(\times 10^{9} / L\right)$ & $32.67 \pm 1.12^{a}$ & $35.00 \pm 2.39^{a}$ & $15.00 \pm 1.46^{b}$ & $29.33+1.28^{a}$ \\
\hline MID $(\%)$ & $12.67 \pm 1.05^{a}$ & $10.00 \pm 0.73^{a}$ & $15.27 \pm 1.77^{b}$ & $17.67 \pm 0.56^{b}$ \\
\hline Platelets (×109/L) & $422.67 \pm 9.71^{b}$ & $461.00+40.98^{b}$ & $381.00+46.84^{a}$ & $535.00+39.85^{c}$ \\
\hline
\end{tabular}

Note: MID is the average of monocytes, eosinophils and basophils.

$N=5, X \pm S E M .^{a-c}$ test values carrying superscripts different from the control across each parameter are significantly different at $P<0.05$ 
Fountain Journal of Natural and Applied Sciences 2017; 6(2): 1 - 8

There were significant $(P<0.05)$ reductions in $A L T$ activity and globulin concentration in a dosedependent manner in all experimental groups when compared with control (Table 2). Significant $(P<0.05)$ elevations were observed in AST activity at 1000 $\mathrm{mg} / \mathrm{kg}$ body weight and GGT activity in all experimental groups in a dose-dependent manner (Table 2). Significant $(P<0.05)$ elevations also exist in total protein and albumin concentrations at 1000 and $1500 \mathrm{mg} / \mathrm{kg}$ body weight which were not dosedependent (Table 2). Percentage liver-body weight ratios were not significantly $(P>0.05)$ different from control. The calculated liver-body weight ratio of the rats showed no significant $(P<0.05)$ difference when compared with the respective control group (Table 2).

Table 2: Effect of aqueous extract of leaf of Senna occidentalis on some liver function parameters of Wistar rats

\begin{tabular}{|c|c|c|c|c|}
\hline \multirow{2}{*}{ Parameters } & \multicolumn{4}{|c|}{ Senna occidentalis aqueous extract ( $\mathrm{mg} / \mathrm{kg}$ body weight) } \\
\hline & Control & 500 & 1000 & 1500 \\
\hline Liver-body weight ratio (\%) & $3.31 \pm 0.06^{a}$ & $3.59 \pm 0.19^{a}$ & $3.62 \pm 0.14^{a}$ & $3.14 \pm 0.10^{a}$ \\
\hline $\begin{array}{c}\text { Alanine aminotransaminase } \\
(U / L)\end{array}$ & $23.00 \pm 9.17^{a}$ & $17.80 \pm 2.95^{b}$ & $17.14 \pm 1.28^{b}$ & $14.60^{-}+2.28^{c}$ \\
\hline $\begin{array}{c}\text { Aspartate } \\
\text { aminotransaminase }(U / L)\end{array}$ & $12.10 \pm 0.82^{a}$ & $11.78 \pm 0.71^{a}$ & $17.40 \pm 1.03^{b}$ & $11.70 \pm 1.57^{a}$ \\
\hline $\begin{array}{c}\text { Gamma Glutamyl transferase } \\
(U / L)\end{array}$ & $141.72 \pm 5.99^{a}$ & $610.38 \pm 4.98^{b}$ & $1062.30 \pm 17.32^{c}$ & $1070 \pm 35.13^{d}$ \\
\hline Total Protein ( $g / L)$ & $8.82 \pm 0.82^{a}$ & $8.67 \pm 0.68^{a}$ & $11.76 \pm 1.05^{c}$ & $10.33 \pm 0.87^{b}$ \\
\hline Albumin (mmol/L) & $3.68 \pm 0.94^{a}$ & $3.77 \pm 0.83^{a}$ & $7.01 \pm 1.13^{c}$ & $5.84 \pm 0.87^{b}$ \\
\hline Globulin (mmol/L) & $5.14 \pm 0.14^{a}$ & $4.91 \pm 0.19^{b}$ & $4.75 \pm 0.18^{b}$ & $4.49 \pm 0.07^{b}$ \\
\hline
\end{tabular}

$(N=5, X \pm S E M)$ Test values carrying superscripts different from the control for each parameter are significantly different ( $p<.05)$
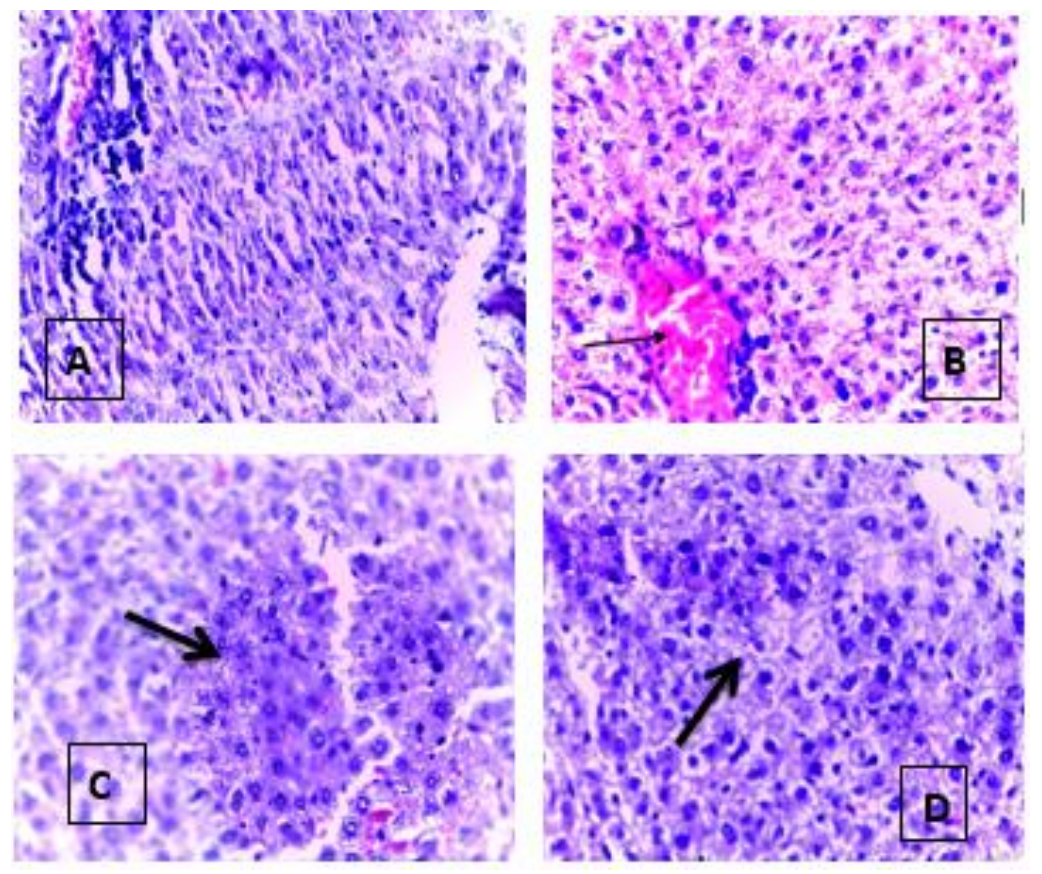
The extract altered the architecture of the liver in all treated groups when compared with the control group (Plates 1: $a, b, c$, and d). The control group showed normal liver cell architecture with the central vein and the portal triad intact while mild disruption of the hepatocytes with thrombosis of the hepatic vesicles at $500 \mathrm{mg} / \mathrm{kg}$ B.W. Mild inflammation and distortion of the liver parenchymal cells were evident in the animals administered 1000 $\mathrm{mg} / \mathrm{kg}$ B.W. Mild inflammation around the portal triads with hepatic structure preserved and no inflammation around or within the central vein was observed in rats administered $1500 \mathrm{mg} / \mathrm{kg}$ B.W.

Plate 1: (a) Photomicrographs cross section of the liver from Wistar rats orally administered $1 \mathrm{ml}$ distilled water for 14 days (Control Group) (b) Cross section of the liver from Wistar rats orally administered $1 \mathrm{ml}$ of $500 \mathrm{mg} / \mathrm{kg}$ body weight of $S$. occindetalis for 14 days (Group 2 ) (c) Cross section of the liver from Wistar rats orally administered 1 $\mathrm{ml}$ of $1000 \mathrm{mg} / \mathrm{kg}$ body weight of S. occindetalis for 14 days (Group 3 ) (d) Cross section of the liver from Wistar rats orally administered $1 \mathrm{ml}$ of $1500 \mathrm{mg} / \mathrm{kg}$ body weight of S. occindetalis for 14 days (Group 4 ) (X 400) haematoxylin and eosin

\section{Discussion}

Evaluation of various hematological parameters can be used to determine the extent of deleterious effect of extracts on the blood of an animal. It can also be used to explain blood-related functions of a plant extract or its products (Yakubu et al., 2007; Periyar et al., 2014). Blood tests can also be used to determine the dehydration state, severity of anaemia, infection and immune challenge, physical stress as well as metabolic conditions (Kohnke, 2009). These undesirable effects may be attributable to xenobiotics such as plant extracts and other chemical compounds.

The significant $(p<0.05)$ decrease in $R B C$, haemoglobin, PCV and $M C H C$ may be an indication that the balance between the rate of production and destruction of the blood cells was altered and may result in low oxygen supply to different tissues due to impaired oxygen carrying capacity of the blood (Eyo et al, 2013). MCHC, MCH and MCV relate to individual red blood cells while haemoglobin, $R B C$ and $P C V$ are associated with total population of the red blood cells (Adebayo et al., 2005). Hence, significant decrease in RBC, PCV and haemoglobin due to the administration of the extract could mean that the process of incorporation of the haemoglobin into $R B C$, osmotic fragility of the $R B C$, and subsequent alteration of the movement of oxygen and nutrients within the system have been altered (Iannacone et al., 2005). This observation is in contrast with the report of Ibrahim and his co-researchers (2010) but in agreement with the work of Barbosa-Ferreira et al. (2005). The white blood cells protect the human body by fighting germs and responding to the presence of xenobiotics, including plant extracts, introduced into the system. Increase in WBC, lymphocytes and MID, which is the average of average of monocytes, eosinophils and basophils by the extract at 1000 and $1500 \mathrm{mg} / \mathrm{kg}$ body weight could indicate response to possible extract-mediated inflammation. Also, decrease in neutrophils may indicate immunosuppression since neutrophils constitute the first line of defense (Okon et al., 2011) and decrease in platelets count may result in thrombocytopenia, leading to bleeding disorders, since its decrease may result in decreased platelets (Jimoh et al., 2008). These alterations in the hematological parameters may be an indication of selective toxicity of the extract on the capability of the blood system to perform it functions in the animals and alteration of haemopoiesis process, probably due to its phytochemical constituents, but the detailed mechanism of action is not clear.

Alanine and aspartate aminotransferases are cytosolic enzymes which can be used in assessing the integrity of the liver (Chapatwala et al., 1982). Alterations may be an indication of impaired functional capabilities of the organ. The decrease in ALT activity at all treatment doses may be due to inhibitory effect of the phytoconstituents of the extract while an increase in AST at $1000 \mathrm{mg} / \mathrm{kg}$ body weight may be due to liver impairment (Gifford, 1995).

Gamma-glutamyl transferase is a membranebound enzyme specific for the liver which catalyses the transfer of y-glutamyl group between peptides 
and amino acids (Tate and Ross, 1977). Its increased presence in the serum is an indication of tissue damage, presumably due to leakage through altered cell membrane of the organ (Akanji and Ngaha, 1989, Salau et al., 2015). The dose-dependent increase in serum GGT activities may indicate damage to the plasma membrane of the Liver (Yakubu et al., 2003). This report is in agreement with the report of Salau and his co-researchers that reported increase in gamma-glutamyl transferase levels in Wistar rats due to diethylnitrosamine treatment (Salau et al., 2015).

Levels of total protein, albumin and globulin in the serum can be used as biomarkers of synthetic function of the liver (Yakubu and Musa, 2012; Salau et al., 2015). Elevated concentration of total protein and albumin may indicate impaired synthetic function of the liver especially at $1000 \mathrm{mg} / \mathrm{kg} \mathrm{B}$. W. of the extract. Decreased globulin supports the immunosuppression earlier indicated by the decreased neutrophils since immunoglobulins would be fewer in the animal system, hence, the extract may possess immune-modulating activity.

Alteration in organ-body weight ratio may indicate organ swelling, atrophy or hypertrophy. Amresh et al. (2008) suggested that organ to body weight ratio can be a confirmatory biomarker for impairment in the functionality of the organ because it is late manifestation of tissue impairment. The absence of changes in the liver-body weight ratio may be an indication that the observed effects have not reached the late stage of causing oedema or tissue atrophy. Histopathological examination has been suggested as confirmatory biomarkers of toxicity of xenobiotics (Parasuraman, 2011). Also, histopathological analysis of tissues is a definitive way to diagnose and confirm various types of impairment in tissues (Yang et al., 2014). Presence of inflammation and distortion of cellular architecture observed in the liver architecture of animal model is an affirmation of the toxic effect of Senna occidentalis aqueous leaf extracts administered. This corroborates the inflammatory response indicated by the elevated WBC, lymphocytes and MID earlier discussed. This histologic observation is in agreement with earlier report by Ashafa et al. (2011) and Adebayo et al. (2003) that reported similar alteration with Felicia muricata leaves aqueous extract and Khaya senegalensis ethanol extract.

\section{Conclusion}

The results of the present study have indicated that aqueous leaf extract of $S$. occidentalis exhibited selective toxicity in rats and may pose significant risk if consumed indiscriminately at doses up to and above $500 \mathrm{mg} / \mathrm{kg}$ body weight because of its effect on haematological parameters, serum enzymes, indices of liver function and liver histoarchitecture.

\section{References}

Achterberg, J. (2013). Imagery in healing In: Shamanism and modern medicine. Shambhala Publications.

Adebayo, J. O., Yakubu, M. T., Egwin, E. C., Owoyele, B. V. \& Enaibe, B. U. (2003). Effect of ethanolic extract of Khaya senegalensis on some biochemical parameters of rat kidney. Journal of Ethnopharmacology, 88(1), 69-72.

Adebayo, J., Adesokan, A., Olatunji, L., Buoro, D. \& Soladoye, A. (2005). Effect of ethanolic extract of Baugainvillea spectabilis leaves on hematological and serum lipid variables in rats. Biokemistri , 17, 45-50.

Akanji, M. A. and Ngaha E. O. (1989). Effect of repeated administration of Berenil on urinary enzyme excretion with corresponding tissue pattern in rats. Pharmacology and Toxicology, 64, 272-275.

Amresh, G. R., Singh, P. N., Rao, V. C. (2008). Toxicological screening of traditional medicine Laghupatha (Cissampelos pareira) in experimental animals. Journal of Ethnopharmacology, 116, 454460.

Ashafa A. O. T., Sunmonu, T. O. \& Afolayan, A. J. (2011). Effect of leaf and berry extracts of Phytolacca dioica L. on haematological and weight parameters of Wistar rats. Africa Journal of Pharmacy and Pharmacology, 5, 150-154.

Ashafa A. O. T., Yakubu M. T., Grierson, D. S., and Afolayan, A. J. (2011). Evaluation of aqueous extract of Felicia muricata leaves for Antiimmflamatory anti-nociceptive and antipyretic 
activities. Pharmaceutical Biology, 48(9), 9941001.

Auwioro, O. G. (2010). Histochemistry and tissue pathology principle and techniques $2^{\text {nd }}$ Edition.

Barbosa-Ferreira, M., Dagli, M. L., Maiorka, P. C. \& Gorniak, S. L.(2005). Sub acute intoxication of Senna occidentalis seeds in rats. Food Chemistry and Toxicology, 43, 497-503.

Blench, R. (2007). Hausa names for plant and trees $2^{\text {nd }}$ Edition retrieved from http://www.rogerblench.info/RBOP.htm on 25/10/2014.

Cai, Y. Z., Sun M. \& Corke, H. (2003). Antioxidant activity of betalains from plants of the Amaranthaeceae. Journal of Agricultural and Food Chemistry, 51(8), 2288-2294.

Chapatwala, K., Boykin, M. A. \& Rajanna, B. (1982). Effects of intraperitoneally injected cadmium on renal and hepatic glycogenic enzymes in the rat. Drug and Chemical Toxicology, 5, 305-317.

Debelo, N., Afework, M., Debella, A., Makonnen, E., Ergete W, and Geleta, B. (2016). Assessment of hematological, biochemical and histopathological effects of acute and sub-chronic administration of the aqueous leaves extract of Thymus schimperi in rats. Journal of Clinical Toxicology, 6 , 286-292. doi:10.4172/2161-0495.1000286.

Eyo, J. E., Nwachukwu, L. O., Onah, I. E., Atama, C. I., Ekeh, F. N., Ezenwaji, N. E. \& Ivoke, N. (2013). Effects of the aqueous extract of Vernonia amygdalina on the heamatological profile of Rattus norvegicus. Advances in Life Science and Technology, 11, 19-24.

Gained, K. N., Budhiraja R. D. \& Kaul, R. D. (1966). Antibiotic activity of Cassia occidentalis L. Indian Journal of Pharmaceutical Sciences, 28, 248-250.

Gifford, L. (1995). Low activities of aspartate and alanine aminotransferase (their significance in alcoholic liver disease). Laboratory Medicine, 26(4), 273-276.

Grant, G. H., Silverman, L. M. \& Christenson, R. H. (1987). Amino acids and proteins. In: Fundamentals of Clinical Chemistry. Tietz, N. W. Ed., Third Edition, WB Saunders Company Philadelphia USA, pp. 328-329.
Haselwood, E. L. \& Motter G. G. (1966). Handbook of Hawaiian Weeds. Hawaiian Sugar Planters' Association, Honolulu, HI., USA pg. 479.

Henry, J. B. (1984). Clinical Diagnosis and Management by Laboratory Methods, 17th ed. WB Saunders Co., 1984, p. 1437.

Henty, E. E., Pritchard, G. H., \& Owner, F. (1975). Weeds of New Guinea and their Control. $2^{\text {nd }}$ Edn. Division of Botany, Dept. of Forests. Papua New Guinea, pg 180.

Iannacone, M., Sitia, G., Isogawa, M., Marchese, P., Castro, M. G., Lowenstein, P. R., Chisari, F. V., Ruggeri, Z. M. \& Guidotti, L. G. (2005). Platelets mediate cytotoxic $T$ lymphocyte-induced liver damage. Nature Medicine, 11 (11), 1167-1169.

Ibrahim, M. A., Aliyu, A. B., Sallau, A. B., Bashir M., Yunusa, I. \& Umar, T. S. (2010). Senna occidentalis leaf extracts possesses antitrypanosomal activity and ameoliorates the trypanosome-induced anemia and organ damage. Pharmacognosy Research, 2(3), 175-10. dio 10.4103/0974-8490.65513.Isah, T. \& Mujib, A. (2013). In vitro plant regeneration of coffee senna (Senna occidentalis) from hypocotylderived callus. Acta Biologica Cracoviensia, 55(2), 120-125.

Jimoh, O. R., Olaore, J., Olayaki, L., Olawepo, A. \& Bilimaminu S. (2008). Effect of aqueous extract of Ocimum gratissimum on haematological parameters of Wistar rats. Biokemistri, 20(1), 3337.Kohnke, J. (2009). Blood Counts: A Practical Guide to Common Problems. Retrieved from http://www.kohnkesown.com.loodcounts on 20/09/2015.

Krause WJ (2001). The art of examining and interpreting histologic preparations. A student handbook. Partheton Publishing Group, UK. 9-10.

Nwaehujor, C. O., Ode, O. J. \& Okoye, D. N. (2011). The hepatoprotective effect of Senna occidentalis methanol leaf extract against acetaminophen-induced hepatic damage in rats. Journal of Pharmacology and Toxicology, 6(7), 637-646.

Odeja, O., Obi, G., Ogwuche, C. E., Elemike, E. E. \& Oderinlo, Y. (2016). Phytochemical screening, antioxidant and antimicrobial activities of Senna occidentalis (L.) leaves extract. Clinical 
Phytoscience, 1, 6-11. DOI 10.1186/s40816-0150007-y

Okon, U. A., Ita, S. O., Ekpenyong, C. E., Davies, K. G. \& Inyang, O. I. (2011). Reduction of platelet and lymphocyte counts and elevation of neutrophil counts in rats treated with aqueous leaf extract of Ocimum gratissimum. African Journal of Biochemistry Research, 5(9), 303-306.

Parasuraman, S. (2011). Toxicological screening. Yohimbine, 2 (2), 74-79. http://doi.org/10.4103/0976-500X.81895.

Periyar, S. S., Palanisamy, A., Sharida, F. \& Murugesan, K. (2014). Beneficial effects of mangiferin isolated from Salacia chinensis on biochemical and hematological parameters in rats with streptozotocin induced diabetes. Pakistan Journal of Pharmacuetical Sciences, 27(1), 161167.

Salau, A. K., Yakubu, M. T. \& Oladiji, A. T. (2015). Hepatoprotective effects of aqueous root bark extracts of Anogeissus leiocarpus, Terminalia avicennioides, and their mixture in diethylnitrosamine-treated rats. Drug Development \& Therapeutics, 6, 93-100.

Szasz, G. \& Bergmeyer, H. U. (1974). Methods of Enzymatic Analysis. $2^{\text {nd }}$ edition, Weinheim Verlag Chemie.

Tate, S.S. \& Rose, M. E. (1977). Human kidney gammaglutamyl transpeptiadase: catalytic properties, subunit, structure and localization of the gammaglutamyl transpeptidase site on the large subunit. Journal of Biological Chemistry, 252, 6042-6045.

Tietz, N. W. (1994). Textbook of Clinical Chemistry. 2nd ed. W.B. Saunders Co., pp. 717-723.

Timm, C. D. \& Riet-Correa, F. (1997). Plant toxic to pigs. Ciencia Rural, 27, 521-528.

World Health Organization (2008). Traditional Medicine fact sheet No 134 retrived from www.who.int/mediacentre.factsheets/fs134.en/ on $18 / 12 / 2014$.

Yakubu, M. T., Akanji, M. A. \& Oladiji, A. T. (2007). Heamatological evaluation in male albino rats following chronic administration of aqueous extract of Fadogia agrestis stem. Pharmacognosy Magazine, 3(9), 34-38.

Yakubu, M. T., Bilbis, L. S., Lawal, M. \& Akanji, M. A. (2003). Evaluation of selected parameters of rat Liver and kidney function following repeated administration of yohimbine. Biokemistri, 15, 5056.

Yakubu, M. T. \& Musa, I. F. (2012). Liver and kidney functional indices of pregnant rats following the administration of the crude alkaloids from Senna alata (Linn. Roxb) leaves. Iranian Journal of Toxicology, 6(16), 615-625.

Yang, X., Schnackenberg, L. K.,Shi, Q. \& Salminen, W. F. (2014). Hepatic toxicity biomarkers. In: Biomarkers in Toxicology Gupta, R (Ed)) pp. 241259. DOI: $h t+p: / / d x$.doi.org/10.1016/B978-0-12404630-6.00013-0.

Zheng, W. \& Wang, S. Y. (2003). Antioxidant activity and phenolic compounds in selected herbs. Journal of Agricultural and Food Chemistry, 49(11), 51655170. 